\title{
The Effect of Haemostatic Dressing Prototypes for the Emergency Services in the Porcine Haemostatic System
}

\author{
ZBIGNIEW ADAMIAK ${ }^{1}$, JAN BORYS ${ }^{2}$, WIOLETTA KRYSTKIEWICZ ${ }^{3}$, \\ ANDRZEJ POMANIOWSKI ${ }^{3}$, MAREK JALYNSKI ${ }^{1}$, PIOTR HOLAK $^{1}$, MACIEJ BRZEZINSKI ${ }^{4}$, \\ PAWEL JASTRZEBSKI ${ }^{5}$, ANGELIKA TOBOLSKA ${ }^{1}$ and JOANNA GLODEK ${ }^{1}$ \\ ${ }^{1}$ Department of Surgery and Radiology, Faculty of Veterinary Medicine, \\ University of Warmia and Mazury in Olsztyn, Olsztyn, Poland; \\ ${ }^{2}$ Department of Craniomaxillofacial Surgery, USK Białystok, Białystok, Poland; \\ ${ }^{3}$ Department of Internal Medicine, Faculty of Veterinary Medicine, \\ University of Warmia and Mazury in Olsztyn, Olsztyn, Poland; \\ ${ }^{4}$ Department and Clinic of Cardiac and Vascular Surgery, Faculty of Medicine, \\ Medical University of Gdańsk, Gdańsk, Poland; \\ ${ }^{5}$ Faculty of Health Science, University of Warmia and Mazury, Olsztyn, Poland
}

\begin{abstract}
Background/Aim: Coagulopathy can develop when hemostatic dressings are used to stop massive bleeding, even in patients without prior history of clotting disorders. The selection of procoagulants, which effectively control bleeding and prevent disseminated intravascular coagulation (DIC) and thrombosis, is a significant challenge. The aim of this study was to evaluate the effect of two prototypes of haemostatic dressing in the porcine haemostatic system. Materials and Methods: The total number of animals used in our experiments was 24. Group I: pigs were treated with the developed prototype of sponge dressing, made of $\mathrm{Na}-\mathrm{Ca}$ chitosan/algal composite of microfibers and nanofibers. Group II: animals were treated with a seton gauze modified with a polymer mixture of $\mathrm{Na}-$ Ca chitosan/algal composite of microfibers and nanofibers. Group III: animals were treated with non-hemostatic dressing and this group was the control. Blood was sampled five times to determine changes in the coagulation and fibrinolytic profiles: before injury: i) at $1 \mathrm{~h}$, ii) at $24 \mathrm{~h}$, iii) at 7, and iv) at 14 days following injury. Results: Significant changes were observed in the coagulation parameters, in the total numbers of white blood cells and platelets in groups I
\end{abstract}

This article is freely accessible online.

Correspondence to: Angelika Tobolska, Department of Surgery and Radiology, Faculty of Veterinary Medicine, University of Warmia and Mazury in Olsztyn, Oczapowskiego 14, 10-957 Olsztyn, Poland. Tel: +48 697935047,e-mail: angelika.tobolska@uwm.edu.pl

Key Words: Haemorrhage, haemostatic dressing, pigs. and II, compared to controls. Conclusion: The modified haemostatic dressings used in this study produced a strong procoagulant effect in pigs. This, together with high fibrinogen concentrations, which can cause DIC, require further studying.

The main role of haemostasis is to maintain the fluidity of the circulating blood, preserve the integrity of the intravascular compartment and prevent blood loss when the endothelial continuity in blood vessels is broken. The pathophysiology of haemostasis can be described by the interaction between coagulation, anticoagulation and fibrinolysis (1). Thrombin is the main enzyme responsible for blood clotting. It converts soluble fibrinogen to insoluble fibrin via extrinsic and intrinsic cellular pathways (2).

Extensive injuries accompanied by severe bleeding pose a life-threatening risk. Trauma-induced haemorrhaging can cause coagulopathy, even in patients without a prior history of clotting disorders (3). This process can be exacerbated when haemostatic dressings are used to stop massive bleeding (4).

Haemostasis is a complex process of attaining an equilibrium between various factors that inhibit and activate blood clotting (5). In serious injuries, the use of procoagulants to manage bleeding can lead to thrombosis and disseminated intravascular coagulation (DIC) (6). DIC is caused by the widespread activation of the clotting cascade and the generation of large amounts of fibrin. Fibrin binds to the surface of platelets and leads to the formation of blood clots (7). In DIC, the function of coagulation inhibitors, in particular of antithrombin (AT) and protein C, is impaired, leading to excessive production of thrombin (8). 
Table I. Analysed hematological parameters.

\begin{tabular}{lcc}
\hline The white blood cell system & The red blood cell system & The platelet system \\
\hline White blood cell (WBC) & Red blood cell (RBC) & Platelet (PLT) \\
& Haematocrit (HCT) & Mean platelet volume (MPV) \\
& Haemoglobin concentration (HGB) \\
Mean corpuscular volume (MCV) & Mean corpuscular haemoglobin (MCH) \\
& Mean corpuscular haemoglobin Concentrations (MCHC) & \\
\hline
\end{tabular}

In the process of developing new types of haemostatic dressings, the selection of procoagulants of optimal quality and with a concentration that can effectively control bleeding and prevent DIC and thrombosis, is a significant challenge. Scientists continue to search for the ideal haemostatic dressing that would effectively manage massive bleeding without exerting adverse effects on human and animal haemostasis (9).

This study aimed to evaluate the effect of two prototypes of haemostatic dressings on the uniformed services of the porcine haemostatic system.

\section{Materials and Methods}

The study was approved by the Institute for Animal Welfare and the Bioethics Committee. All animals were handled humanely in compliance with the Policy on Humane Care and Use of Laboratory Animals and the standards of the Polish Council on Animal Care. The experiments were also approved by the Local Committee for Animal Care in Olsztyn (Decision No.44/2014/N).

The total amount of animals used in this experiment was 24 . The animals were injured by a surgical incision of $3 \mathrm{~cm}$ at the left inguinal fossa and the underlying femoral artery, using a sterile scalpel blade under general anaesthesia. The following agents were used before the surgery: i) atropine (Atropinum Sulfuricum, PolfaWarszawa, Warsaw, Poland) at $0.05 \mathrm{mg} / \mathrm{kg}$ (IM), and ii) azaperone (Stresnil, Janssen Pharmaceutica N.V. Tumhoutseweg, Beerse, Belgium) at $2.5 \mathrm{mg} / \mathrm{kg}$ (IM). General anaesthesia was induced with ketamine (Bioketan, Vetoquinol, Gorzów Wielkopolski, Poland) at $8 \mathrm{mg} / \mathrm{kg}$ (IM) and was maintained with propofol (Scanofol, Vetoquinol, Gorzów Wielkopolski, Poland) at $10 \mathrm{mg} / \mathrm{kg}$ (IV). The pain was managed with buprenorphine (Bupaq Multidose, Richter Pharma, Austria) at $0.01 \mathrm{mg} / \mathrm{kg}$ (IM). Selected haemostatic dressings were applied to the wound depending on the group to control bleeding from the surgically incised femoral arteries. Group I (G) pigs $(n=8)$ were treated with the developed prototype of the dressing sponge made of $\mathrm{Na}-\mathrm{Ca}$ chitosan/algal composite of microfibers and nanofibers. Group II (S) animals $(n=8)$ were treated with a seton gauze modified with a polymer mixture of $\mathrm{Na}-\mathrm{Ca}$ chitosan/algal composite of microfibers and nanofibers. Both types of dressings in groups I and II were coated by chitosan (ChitoClear hqg 95 from Primex ehf Iceland) and sodium alginate (Protanal LF10/60 FT) at a concentration of $18.0 \mathrm{~g} / \mathrm{m}^{2}$ for both. Haemostatic dressings used in a previous study (10) were modified here. Group III (C) animals $(n=8)$ were treated with a type of non-haemostatic dressing and were used as a negative control group. The non-haemostatic dressing was a standard pressure dressing, which covered the surgical incision with a gauze kept in place with a bandage. Blood samples were collected from all pigs for comparative analyses. Blood for haematology was collected into test tubes coated with EDTAK2 (ethylenediaminetetraacetic acid dipotassium salt dihydrate), and blood for the coagulation tests was collected into test tubes containing $3.2 \% \mathrm{w} / \mathrm{v}$ sodium citrate. Blood was sampled on five timepoints to determine changes in the coagulation and fibrinolytic profiles: once before the injury, then at 1 hour, at 24 hours, at 7 days and at 14 days following injury. In the group III (C) measurements were made only after 1 hour following injury due to the lack of efficacy of non-haemostatic dressing, which resulted in these animals being not alive at 24 hours after injury. The haematological parameters we considered are presented in Table I.

Blood coagulation efficiency was evaluated by determining the following parameters: i) activated partial thromboplastin time (APTT), ii) prothrombin time (PT), iii) thrombin time (TT), iv) fibrinogen concentrations (FIB), v) D-dimer concentrations (DD), vi) antithrombin III activity (ATIII) and vii) thrombin-antithrombin complex concentrations (TAT).

Data were expressed as the mean $( \pm \mathrm{SD})$ for the 8 animals in each group. Statistical analyses were performed using one-way analysis of variance (ANOVA) followed by the Bonferroni post-hoc test. Differences were determined as significant ones when $p$-values were $\leq 0.05$. SigmaPlot Software Version 12.0 (Systat Software Inc., San Jose, CA, USA) was used for all statistical analyses.

\section{Results}

Haematological analyses. The mean values of all haematological parameters tested are presented in Table II.

Significant changes in whole blood cell (WBC) counts were observed in groups I and II, which increased significantly 24 hours after the induction of injury and remained high in both experimental groups until day 7. Fourteen days later, significant changes were noted in WBC counts between groups I (G) and II (S). In group III (C) WBC counts were dropped after $1 \mathrm{~h}$ following injury, showing a significant difference as compared to groups I (G) and II (S).

No significant changes in red blood cell (RBC) counts were noted in group I. A minor decrease in RBC counts and haemoglobin concentration were observed $1 \mathrm{~h}$ following 
Table II. Mean values of haematological parameters.

\begin{tabular}{|c|c|c|c|c|c|c|c|c|c|c|}
\hline Group & $\begin{array}{c}\text { Sample collection } \\
\text { time }\end{array}$ & $\begin{array}{l}\mathrm{WBC} \\
10^{3} / \mu \mathrm{l}\end{array}$ & $\begin{array}{l}\mathrm{RBC} \\
10^{6} / \mu \mathrm{l}\end{array}$ & $\begin{array}{l}\text { HGB } \\
\mathrm{mmol} / 1\end{array}$ & $\begin{array}{c}\mathrm{HCT} \\
\%\end{array}$ & $\begin{array}{c}\mathrm{MCV} \\
\mathrm{fl}\end{array}$ & $\begin{array}{c}\mathrm{MCH} \\
\mathrm{pg}\end{array}$ & $\begin{array}{c}\mathrm{MCHC} \\
\mathrm{pg} / 1\end{array}$ & $\begin{array}{l}\text { PLT } \\
10^{3} / \mu 1\end{array}$ & $\begin{array}{c}\text { MPV } \\
\mathrm{fl}\end{array}$ \\
\hline \multirow[t]{5}{*}{ G } & 0 ' & $23.87^{\mathrm{a}}$ & 6.53 & 9.92 & $33.32^{\mathrm{a}}$ & 51.09 & 15.24 & 29.81 & $562^{\mathrm{a}}$ & 6.48 \\
\hline & $1 \mathrm{~h}$ & $22.54^{\mathrm{aA}}$ & 5.78 & 8.65 & $28.98^{\mathrm{b}}$ & $50.54^{\mathrm{A}}$ & 15.03 & 29.96 & $489^{b}$ & $6.61^{\mathrm{A}}$ \\
\hline & $24 \mathrm{~h}$ & $31.05^{\mathrm{b}}$ & 5.97 & 8.91 & $29.24^{\mathrm{b}}$ & 49.11 & 14.97 & 30.44 & $565^{\mathrm{a}}$ & 6.44 \\
\hline & 7 days & $30.24^{b}$ & 5.88 & 8.76 & $29.17^{\mathrm{b}}$ & 49.72 & 14.93 & 29.99 & $617^{\mathrm{a}}$ & 7.08 \\
\hline & 14 days & $21.69^{\mathrm{aA}}$ & 5.6 & 9.15 & $30.35^{\mathrm{b}}$ & 54.25 & $16.30^{\mathrm{A}}$ & 30.05 & $845^{\mathrm{c}}$ & $7.00^{\mathrm{A}}$ \\
\hline \multirow[t]{5}{*}{ S } & $0^{\prime}$ & $20.12^{\mathrm{a}}$ & $6.61^{\mathrm{a}}$ & $10.11^{\mathrm{a}}$ & $33.73^{\mathrm{a}}$ & 50.92 & 15.26 & 30.0 & $470^{\mathrm{a}}$ & 7.10 \\
\hline & $1 \mathrm{~h}$ & $20.03^{\mathrm{aA}}$ & $5.93^{\mathrm{bc}}$ & $9.06^{\mathrm{ab}}$ & $30.20^{\mathrm{bc}}$ & $50.66^{\mathrm{A}}$ & 15.28 & 30.0 & $491^{\mathrm{a}}$ & $6.43^{\mathrm{A}}$ \\
\hline & $24 \mathrm{~h}$ & $28.10^{\mathrm{b}}$ & $6.14^{\mathrm{ab}}$ & $9.5^{\mathrm{a}}$ & $31.24^{\mathrm{ab}}$ & 50.29 & 15.30 & 30.0 & $599^{a}$ & 6.45 \\
\hline & 7 days & $27.42^{b}$ & $5.39^{\mathrm{c}}$ & $8.3^{\mathrm{b}}$ & $27.06^{\mathrm{c}}$ & 50.36 & 15.43 & 31.0 & $780^{\mathrm{b}}$ & 6.75 \\
\hline & 14 days & $18.98^{\mathrm{aB}}$ & $6.10^{\mathrm{ab}}$ & $9.62^{\mathrm{a}}$ & $32.16^{\mathrm{a}}$ & 52.82 & $15.76^{\mathrm{B}}$ & 29.84 & $693^{c}$ & $7.64^{\mathrm{B}}$ \\
\hline \multirow[t]{2}{*}{$\mathrm{C}$} & $0^{\prime}$ & 16.76 & 6.15 & 9.98 & 32.56 & 55.80 & 16.63 & 31.15 & 395.0 & 8.06 \\
\hline & $1 \mathrm{~h}$ & $18.77^{\mathrm{B}}$ & 5.78 & 9.48 & 30.97 & $55.85^{\mathrm{B}}$ & 15.53 & 29.35 & 365.5 & $8.67^{\mathrm{B}}$ \\
\hline
\end{tabular}

WBC, White blood cell; RBC, red blood cell; HGB, haemoglobin concentration; HCT, haematocrit; MCV, mean corpuscular volume; MCH, mean corpuscular haemoglobin; MCHC, mean corpuscular haemoglobin concentrations; PLT, platelet counts; MPV, mean platelet volume. ${ }^{\mathrm{a}, \mathrm{b}, \mathrm{c}} p \leq 0.05$, different letters mean significant differences between sampling time in each group; ${ }^{\mathrm{A}, \mathrm{B}} p \leq 0.05$, different letters mean significant differences between groups in each time.

Table III. Mean values of coagulation parameters.

\begin{tabular}{|c|c|c|c|c|c|c|c|c|}
\hline Group & $\begin{array}{c}\text { Sample collection } \\
\text { time }\end{array}$ & $\begin{array}{l}\text { APTT } \\
\text { s }\end{array}$ & $\begin{array}{c}\mathrm{TT} \\
\mathrm{s}\end{array}$ & $\begin{array}{c}\mathrm{PT} \\
\mathrm{s}\end{array}$ & $\begin{array}{c}\text { FIB } \\
g / 1\end{array}$ & $\begin{array}{l}\mathrm{DD} \\
\mu \mathrm{g} / 1\end{array}$ & $\begin{array}{c}\mathrm{ATIII} \\
\%\end{array}$ & $\begin{array}{c}\mathrm{TAT} \\
\mathrm{ng} / \mathrm{ml}\end{array}$ \\
\hline \multirow[t]{5}{*}{ G } & 0 ' & $24.9^{\mathrm{a}}$ & $15.98^{\mathrm{a}}$ & 11.65 & $8.51^{\mathrm{a}}$ & $248^{a}$ & $141^{\mathrm{a}}$ & $48^{a}$ \\
\hline & 1 hour & $31^{\mathrm{b}}$ & $12^{\mathrm{bA}}$ & 11.7 & $6.83^{\mathrm{bA}}$ & $535^{\mathrm{b}}$ & $103^{b}$ & $56^{\mathrm{a}}$ \\
\hline & 24 hours & $33^{b}$ & $9^{c}$ & 12.24 & $12.6^{\mathrm{c}}$ & $519^{\mathrm{b}}$ & $129^{a}$ & $134^{\mathrm{b}}$ \\
\hline & 7 days & $34^{b}$ & $11^{\mathrm{d}}$ & 10.9 & $8.43^{\mathrm{a}}$ & $667^{c}$ & $145^{\mathrm{a}}$ & $101^{\mathrm{c}}$ \\
\hline & 14 days & $31^{\mathrm{b}}$ & $13^{\mathrm{eA}}$ & 10.9 & $6.41^{\mathrm{b}}$ & $681^{\mathrm{cA}}$ & $183^{c}$ & $32^{\mathrm{aA}}$ \\
\hline \multirow[t]{5}{*}{ S } & $0^{\prime}$ & $25^{\mathrm{a}}$ & $15.53^{\mathrm{a}}$ & 11.38 & $8.56^{\mathrm{a}}$ & $270^{\mathrm{a}}$ & $150^{\mathrm{a}}$ & $43^{\mathrm{a}}$ \\
\hline & 1 hour & $31^{\mathrm{b}}$ & $12.75^{\mathrm{bA}}$ & 12.01 & $8.33^{\mathrm{aB}}$ & $586^{\mathrm{b}}$ & $102^{\mathrm{b}}$ & $60^{\mathrm{a}}$ \\
\hline & 24 hours & $32^{b}$ & $9.1^{\mathrm{c}}$ & 11.6 & $11.8^{\mathrm{b}}$ & $554^{\mathrm{b}}$ & $127^{\mathrm{c}}$ & $126^{\mathrm{b}}$ \\
\hline & 7 days & $35.5^{\mathrm{c}}$ & $10.6^{\mathrm{d}}$ & 11.09 & $9.41^{\mathrm{a}}$ & $585^{\mathrm{b}}$ & $149^{a}$ & $102^{\mathrm{c}}$ \\
\hline & 14 days & $33.56^{\mathrm{c}}$ & $12.42^{\mathrm{e}}$ & 10.88 & $6.61^{\mathrm{c}}$ & $704^{\mathrm{cB}}$ & $187^{d}$ & $39^{\mathrm{aB}}$ \\
\hline \multirow[t]{2}{*}{$\mathrm{C}$} & $0^{\prime}$ & 29.57 & 21.83 & 11.21 & 8.55 & 366.75 & 113.16 & 30.66 \\
\hline & 1 hour & 29.75 & $19.06^{\mathrm{B}}$ & 10.6 & $9.48^{\mathrm{B}}$ & 493.25 & 95.33 & 44.33 \\
\hline
\end{tabular}

APTT, Activate partial thromboplastin time; PT, prothrombin time; TT, thrombin time; FIB, fibrinogen concentrations; DD, D-dimer concentrations; ATIII- antithrombin III activity; TAT, thrombin-antithrombin complex concentrations. a,b,c,d,e $p \leq 0.05$, different letters mean significant differences between sampling time in each group; $\mathrm{A}, \mathrm{B} p \leq 0.05$, different letters mean significant differences between groups in each time.

injury in group I and III. In group III, only one measurement of these parameters is noted because these animals were treated with a non-haemostatic dressing. However, significant changes in RBC counts were observed in group II 1 hour following injury with a dramatic decrease in haemoglobin concentration on day 7 following injury.

In group I (G), platelet (PLT) counts decreased significantly 1 hour following injury but they increased significantly from $24 \mathrm{~h}$ onwards. In group II (S), PLT counts continued to increase throughout the duration of the experiment, with the highest peak on day 7 . Fourteen days following injury, platelet counts decreased significantly in group II (S) and increased significantly in group I (G).

Statistically significant differences were also noted between groups I (G) and II (S) in mean corpuscular haemoglobin $(\mathrm{MCH})$ and mean corpuscular volume (MPV) values 14 days following injury.

Coagulation analyses. The mean values of the coagulation parameters are presented in Table III.

In groups I (G) and II (S), a significant increase in APTT was noted during the very first hour following injury and 
continued to increase until day 14, whereas this parameter remained stable in group III (C) animals for the first hour following injury.

Thrombin time significantly decreased considerably until day 7 in both groups I (G) and II (S). This parameter significantly increased 14 days following injury. Significant differences in thrombin time were also observed between these groups and group III (C) 1 hour after injury. In group III the parameter was significantly higher compared to the other two groups.

Significant changes were observed in the concentration of the remaining coagulation parameters; i) fibrinogen, ii) Ddimer, iii) antithrombin III activity and iv) thrombinantithrombin complexes. Fibrinogen concentration increased significantly, and DD increased highly significantly $24 \mathrm{~h}$ after injury in both groups I (G) and group II (S). By day 7, FIB values decreased, whereas DD values continued to increase. Fibrinogen concentration was significantly lower in group I (G) 1 hour following injury compared to the other two groups.

The greatest decrease in ATIII values was observed 1 hour following injury in both groups I and II, which continued to increase progressively until day 14 . The observed changes in ATIII values were accompanied by changes in TAT values. In both these groups, TAT increased 1 hour following injury and reached peak value at $24 \mathrm{~h}$ following injury. On day 7 , TAT concentration began to decrease and on day 14 it dropped below the initial value. The statistical analysis also showed significant differences between groups I (G) and II (S) in TAT and DD, with higher values in group II 14 days following injury.

\section{Discussion}

In this study, the observed increase in fibrinogen levels following the use of either type of haemostatic dressing could be indicative of clotting initiation. High fibrinogen concentrations can lead to hypercoagulability and, when other factors are involved, to DIC (11).

High DD values correlate with high concentrations of selected proinflammatory cytokines (12). This correlation suggests that elevated DD and FIB values are linked to thrombosis and inflammation (13).

Significant changes were observed in the activity of antithrombin III and the concentration of the thrombinantithrombin complex. The applied pro-coagulant treatment enhanced the physiological effects of thrombin and activated intrinsic inhibitors, the main one being ATIII. Antithrombin III inactivates thrombin by forming biologically inactive TAT complexes with this enzyme (10). Thrombin-antithrombin complexes have an estimated half-life of $15 \mathrm{~min}$ (14). In both groups I and II, TAT concentrations were high for the first $24 \mathrm{~h}$ following injury. In view of their short half-life, it can be assumed that thrombin degradation was inhibited equally effectively in both groups.

In both groups I and II, platelet counts increased after 7 days following injury. Thrombocytes release adrenalin, noradrenalin, serotonin and thromboxane which promote vasoconstriction and minimise blood loss after injury (10). Aggregating thrombocytes form platelet plugs which prevent bleeding (6). Failure to increase platelet counts immediately after injury could suggest that both haemostatic dressings tested exhibit a strong pro-coagulant effect. The increase in thrombocyte counts 7 days following injury indicates that platelets are involved in intravascular coagulation processes. High platelet counts can increase the risk of venous and arterial thrombosis (15).

The modified haemostatic dressings used in this study had a strong procoagulant effect. Due to a strong reaction and high fibrinogen concentrations, which can cause disseminated intravascular coagulation, further studies with modified dressing types are required.

\section{Funding}

This study was conducted as part of a research project funded by the National Centre for Research and Development, titled: "Wound dressings designed for the uniformed services", No. DOBBIO6/19/98/2014.

\section{Conflicts of Interest}

Authors declare that there are no conflicts of interest.

\section{References}

1 Cines DB, Pollak ES, Buck CA, Loscalzo J, Zimmerman GA, McEver RP, Pober JS, Wick TM, Konkle BA, Schwartz BS, Barnathan ES, McCrae KR, Hug BA, Schmid AM, Stern DM: Endothelial cells in physiology and in the pathophysiology of vascular disorders. Blood 91: 3527-3561, 1998.

2 Jastrzębski P, Adamiak Z, Pomianowski A, Krystkiewicz W, Holak P, Sawicki S, Przyborowska P, Zhalniarovich Y and Gudzbeler G: Response of the coagulation system after the application of haemostatic dressings in an animal model. Pol $\mathrm{J}$ Vet Sci 17: 725-727, 2014.

3 Roissaint R, Boullon B, Cerny V, Coats TJ, Duranteau J, Fernández-Mondéjar E, Filipescu D,Hunt BJ, Komadina R, Nardi G, Neugebauer EAM, Ozier Y, Riddez L, Schultz A, Vincent JL and Spahn DR: The European guideline on management of major bleeding and coagulopathy following trauma. Crit Care 20: 100, 2016.

4 Gruen RL, Brohi K, Schreiber M, Balogh ZJ, Pitt V, Narayan M and Maier RV: Haemorrhage control in severely injured patients. The Lancet 380: 1099-1108, 2012.

5 Spahn DR and Rossaint, R: Coagulopathy and blood component transfusion in trauma. Br J Anaesth 95: 130-139, 2005.

6 Chandler WL: Procoagulant activity in trauma patients. Am J Clin Path 134: 90-99, 2010. 
7 Pourshahrestani S, Zeimaran E, Djordjevic I, Adib Kadri N and Towler MR: Inorganic hemostats: The state-of-the-art and recent advances. Mater Sci Eng C Mater Biol Appl 158: 1255-1258, 2016.

8 Chojnowski K: D-dimer - diagnostics and prognostic marker of venous thromboembolism [in Polish]. Hematologia 1: 102-107, 2010 .

9 Adamiak Z, Jastrzebski P, Pomianowski A, Otrocka-Domagala I, Holak P, Zhalniarovich Y, Przyborowska P and Głodek J: Effect of 24 hour application of three haemostatic dressings to porcine thigh muscles. Pol J Vet Sci 17: 519-521, 2014.

10 Adamiak Z, Krystkiewicz W, Pomianowski A, Bukowiecka D, Zubrzycki W, Jałyński M, Holak P, Głodek J and Jastrzębski P: The effect of haemostatic dressing prototypes for the uniformed services on selected blood coagulation parameters in pigs. Acta Vet Scand 59: 29, 2017.

11 Li J, Cao W, Lv XX, Jiang L, Li YJ, Li WZ, Chen SZ and Li XY (2013): Zeolite-based hemostaz QuikClotrelases calcium into blond and promotes blond coagulation in vitro. Acta Pharmacol Sin 34: 367-372, 2013.
12 Travers S, Dubourg O, Ribiero Parenti L, Lefo(rt H, Albarello S and Domanski L: Prehospital use of haemostatic dressing QuikClot ACS+TM for hemorrhage control of a perineal trauma. Ann Fr Anesth Reanim 31: 969-971, 2012.

13 Jastrzębska M: Laboratory diagnostics in haemostasis [in Polish]. Oinpharma: 235-238, 2009.

14 Żekanowska E, Kotschy M, Rość D, Missima M, Ogorzeja W and Kotschy D: Thrombin-antithrombin III (TAT) complexes during coronary artery bypass grafting with and without extracorporeal circulation. Folia Cardiol 11: 839-845, 2004.

15 Lowe GD: Common risk factors for both arterial and venous thrombosis. Br J Haematol 140: 488-495, 2008.

Received December 6, 2018

Revised December 27, 2018

Accepted January 3, 2019 